\title{
Brazilian Cannibals in Sixteenth-Century Europe and Seventeenth-Century Japan
}

\author{
RADU LECA
}

You come back home in the evening. You turn on the TV. There is a special programme on CCS channel tonight on 'Brazilian cannibals'. I am your host, Radu Leca. ${ }^{\mathrm{I}} \mathrm{I}$ appear in a TV studio room with three screens. Each screen shows a group of researchers gathered around a table in an interrogation room. One side of each interrogation room has a one-way mirror, through which the researchers are watching a lively gathering of historical characters in another room.

Our topic today is the curious adventures of images of Brazilian cannibals in Europe and then in Japan. Using the method of narrative inquiry, ${ }^{2}$ we will look at three case studies: bestselling travelogues about ruthless Brazilian tribes, Jesuit propaganda ending up as broadsheets in Japan, and mountain people feeding on princess thighs. We will discuss how the peripheral location of cannibals was precisely the reason why they were able to play a central role in intercultural communication and intracultural identity formation.

The first gathering is a banquet on the upper floor of an Amsterdam herenhuis (townhouse) in I595. Round the table decked with stuffed pigs and clinking glasses are various travellers to Brazil, sharing their adventures. At the head of the table is the host, Linschoten, a distinguished Dutch gentleman, who has assembled everyone in order to hear their stories and include them in his travelogue Itinerario, just in time for the First Dutch Voyage to the East Indies. ${ }^{3}$ In the corner is a thin, bearded fellow called Hans Staden. He was the first non-Catholic to publish his Brazilian adventures (it is a Protestant gathering, although everybody is drinking). He was shipwrecked and spent ten months as 
a captive of the Tupin-Ikins tribe, one of the Tupinamba tribes in the region of Brazil between Camamu and São Mateus, south of Salvador de Bahia. Upon returning to Europe, he published an account of his travels in Marburg in I 557. He is shy and introverted, but if you ask him, he will open his eyes wide and say: it is with these very eyes that I saw their feasts! He points to a page in his book:

The girdirons are looked unto by the other women, that are very delirous of mas flesh, where they sit and licke up the fat that droppeth off the quarters $[\ldots]$ they make great joy, leaping, skipping, and with most fierce countenances beholding the rosted quarters, everie man taking a peece, not for hunger, or desire of eating, (as some would think) or because without all doubt mans flesh is verie savorie, but rather in respect of revenge, specially the olde women, that are most ravenous of mans flesh, for their intent is onely to gnaw the flesh of their enemies to the bare bones, thereby to putte the rest of the prisoners (as then not slaine) in greater feare, for that to satisfie their monstrous and greedie desires, there is not one peece of the whole body, not so much as their fingers endes, nose, and eares, but by them is eaten. ${ }^{4}$

Next to him is the Franciscan chaplain André Thevet, who visited Brasil with chevalier Nicolas Durand de Villegagnon to establish a French colony in South America. He published his story in ${ }^{5} 55^{8}$ as Les singularitez de la France antarctique autrement nommée Amérique. He is giving drinks to Staden, asking for all the juicy details. Further on, with his back to Thevet, the Huguenot reverend Jean de Léry has stood up, red-faced, and is shouting invectives at Catholics. His Historia Navigationis in Brasiliam, quae et America Dicitur appeared in ${ }_{578} 8$. Theodore de Bry, scribbling while hunched in his seat, featured the Brazilian cannibals on the frontispiece of the third volume in the America series of his Grands Voyages, in I 590.

In the other room, our academic guests are mainly historians of European expansion and anthropologists. They see the banquet, but cannot hear the discussion. They are flicking through the travelogues on the table. Historian Joan-Pau Rubiés starts out by proposing 'a broader reflection about the way artistic images with ethnographic subjects can be used as historical evidence'. ${ }^{5}$ Rubiés points out that 'Europeans only saw what they expected to see', and 'sought to "domesticate" such [radical cultural] differences according to pre-established cultural patterns' ${ }^{6}$

The discussion focuses on this 'reflective' strategy of epistemological interpretation. It originates in anthropological studies such as the I979 The Man-Eating Myth by William Arens, which analysed not cannibalistic practices themselves, but the discourse of cannibalism. ${ }^{7}$ 
Rubiés points out the need to differentiate 'primary mental images that in turn generated original literary and artistic representations, from those secondary mental images that were produced when Europeans subsequently read and interpreted any published accounts' ${ }^{8}$ In other words, there was a shift in the relationship between image and text: 'the woodcuts accompanying the narratives by Hans Staden, André Thevet and Jean de Léry represent a new mode, prevalent in the second half of the $\mathrm{I} 6^{\text {th }}$ century, where the writers played a role in the preparation of the images'. ${ }^{9}$ The visual material was seen as crucial to the validation of the 'truth' of the travel account. ${ }^{\text {Io }}$ Anthropologist Neil Whitehead states that Staden's True History 'visually explodes onto the sixteenth century scene, vastly increasing the visual repertoire for depictions of native Brazilians, and bringing to this repertoire new elements that are in turn taken up by other illustrators'. However, all visualizations of Brazilian cannibalism after Hans Staden's I 557 edition 'altered the content of those images', introducing 'visual suggestions of uncontrolled and depraved female sexuality, child-abuse and satanic witchcraft' ${ }^{\text {II }}$ Tupinamba tribe members were depicted with poses from the Greco-Roman sculptural tradition, not unlike contemporary European erotic engravings (see Figs. I and 2). ${ }^{12}$ The difference in visual language between Staden's and de Bry's illustrations are indicative of a change in the relationship with the cannibal Other: Staden depicts himself intermingling with the Tupinamba tribesmen - the illustrations underscore his intimacy with the Other, which has the potential of leading to a change in identity. In contrast, de Bry's version has excised images of anthropophagy from the experience of meeting the cannibal Other. By introducing classical nudity, de Bry turned Brazilian cannibalism into a familiar visual spectacle, exterior to the viewer and therefore non-problematic to the viewer's identity.

Anthropologist Bernadette Bucher helps us understand how de Bry's illustrations worked. Bucher introduces a structuralist analysis to explicate the division of labour along criteria of age, gender, liquid/solid, raw/cooked and nude/clothed. For example, youngsters are depicted eating only roasted meat, while old women only raw blood and fat. Bucher also notes how cannibalism was seen as a 'regressive process', which for writers such as Jean de Léry triggered condemnations of cannibalistic practices undertaken by Catholics during warfare in Europe. ${ }^{13}$

The cannibal thus became a generic signifier of alterity, employed reflectively as rhetorical tropes in cultural debates of sixteenth-century 


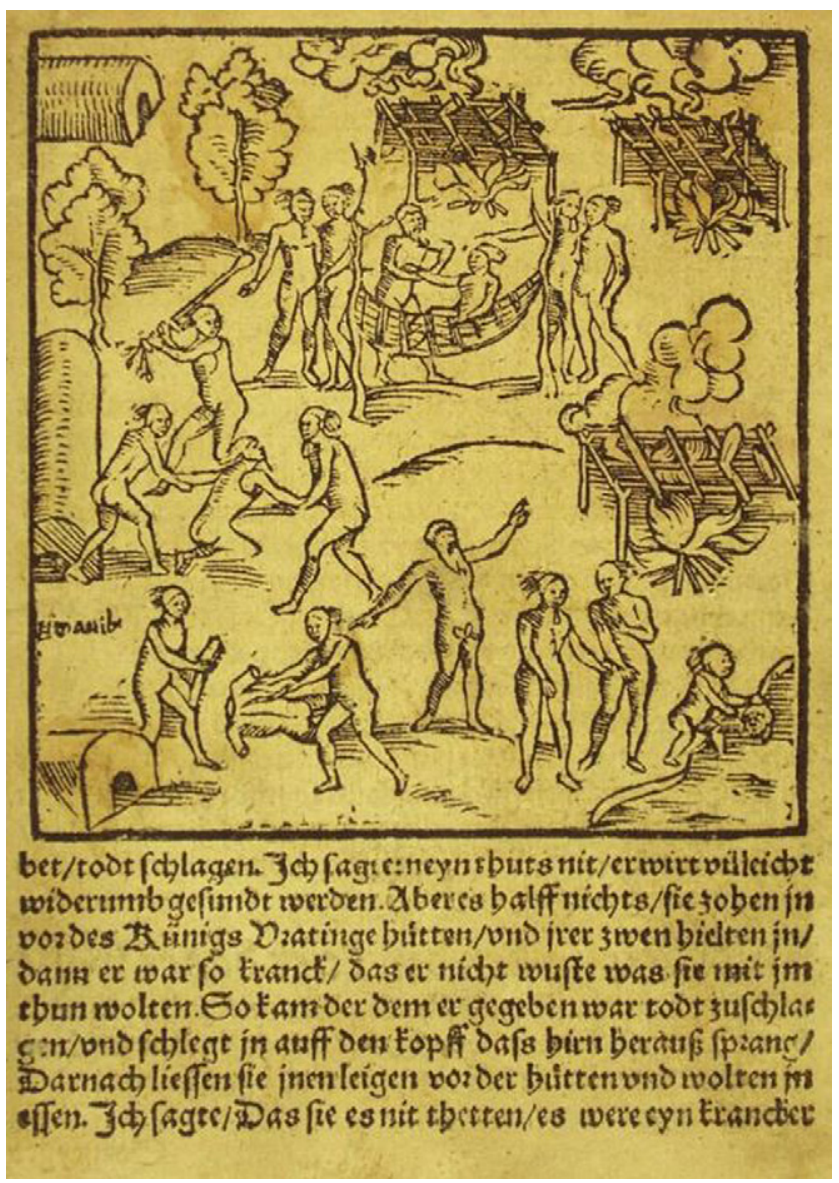

Figure I. Woodcut illustration from Hans Staden, Warhaftige Historia und beschreibung eyner Landschafft der Wilden Nacketen Grimmigen Menschfresser Leuthen in der Nemenwelt America gelegen (Marburg: Andres Kolben, I557), p. 92. Digital image (C) Biblioteca Digital Curt Nimuendajú.

Europe. This cannibal Other was intrinsically ambivalent. ${ }^{\mathrm{I}}$ The members of the Tupinamba tribes were seen as living in a primal utopic state, ${ }^{15}$ but also having to be rescued from barbaric practices by Christianity. Just like representations of witchcraft, their display was an intoxicating blend of visual condemnations of sin and delight in details of deviation. The 'reflective' strategy of interpretation explains why Tupinamba tribe members were drawn as classical figures: what had originally been a source of novelty was assimilated to pre-existing 
DE LA FRANCE ANTARCTIQVE. 77 richement eftoffée de diuers plumages. Et tant plus le prifonnier verra fairc les preparatiues pour mourir, \& plus il monftrera fignes de ioye. Il fera donc mené,bien lié \& garroté de cordes de cotton en la place publique, accompagné de dix ou douze mil Sauuages du païs, fes ennemis, \& la fera affommé cóme vn porceau, apres plufieurs cerimonies. Le prifonnier mort, fa femme,quiluy auoit elté donnée, fera quelque petit dueil. Incontinent le corps eftant mis en pieces, ils en prennent le fang \& è lauent leurs petis enfans mafles, pour les rendre plus hatdis,comme ils difent, leur remonftrans, que quand ils feront venuz à leur aage, ils facent ainfi à leurs ennemis.

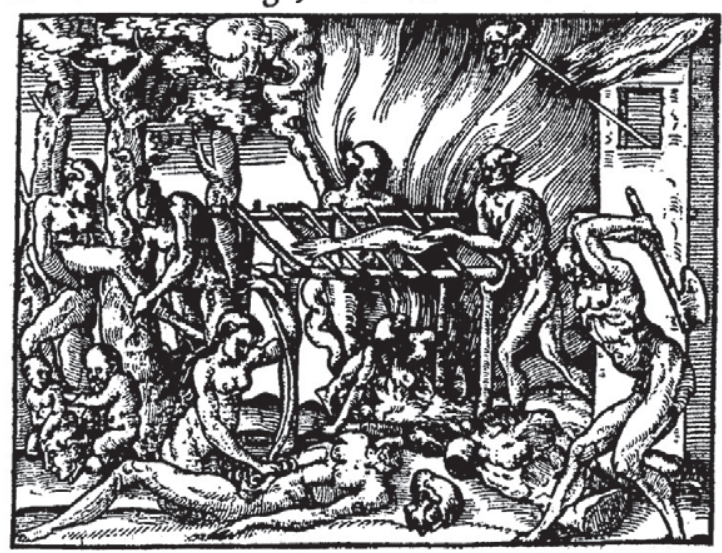

Dont faut penfer, qu'on leur en fait autant delautre part, quand ils font.pris en guerre. Ce.corps ainfi mis par pieces, \& cuit à leur mode, fera diftribué á tous, quelque nó-

Figure 2. Woodcut illustration from André Thevet, Les Singularitez de la France Antarctique autrement nommée Amérique (Paris: Maurice de la Porte, I558), p. 77. Digital image (C) gallica.bnf.fr/Bibliothèque nationale de France.

visual stereotypes of an Other belonging to the distant past. The visual vocabulary for the Other was therefore limited, and interchangeable among temporal and geographical varieties of the Other.

However, sensual and anecdotal visual motifs - human limbs roasting on a gridiron, cut up on a wooden table, or hanging from trees next to Bauhaus-like huts-escape the reflective interpretation. Motifs of cannibalism were de-contextualized and circulated as single sheet prints and cartographic illustrations. ${ }^{16}$ World maps included in one of the most important travelogues of the end of the sixteenth century, 


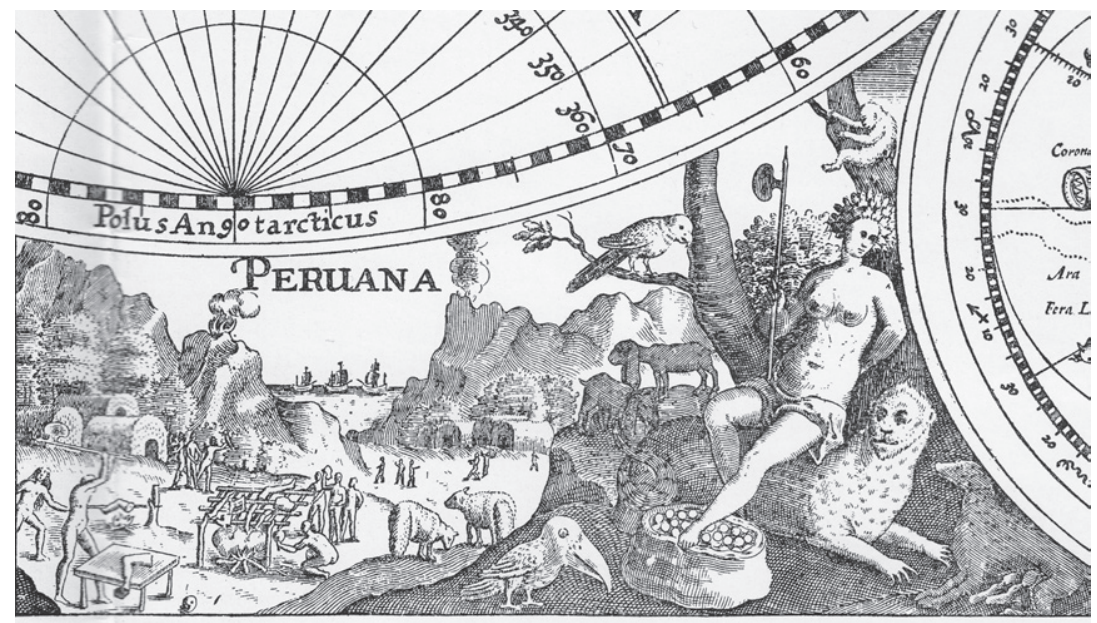

Figure 3. Detail of Orbis terrarum typus de integro multis in locis emendatus auctore Petro Plancio, I 594, attached to Jan Huyghen van Linschoten's Itinerario, I 595. Digital image (C) Stichting Digitale Bibliotheek voor de Nederlandse Letteren (dbnl), Leiden.

Jan Huygen van Linschoten's Itinerario, featured cannibalistic scenes in South America (see Figs. 3 and 4). ${ }^{17}$ Importantly, the Itinerario became 'a regular item on the list of the pilot's equipment', ${ }^{18}$ which is how the European image of Brazil reached Asia, as we will see in the second part of the programme.

I switch off the first TV screen, and switch on the second. A chaya (teahouse) overlooking the bay of Nagasaki, in the r64os. At the front of the room, in the place of honour, sits a daimy $\bar{o}$ (feudal lord), framed by his latest acquisition: a five-metre long folding screen with the map of the world. A cartouche with scenes of cannibals is painted off the coast of South America (see Fig. 5). On the floor in front of him are spread maps from Linschoten's Itinerario. Vis-à-vis, on the tatami mats, his voluble attendant shows the lord a double-fold screen, a smaller copy of the first, to be sent to a lower-ranking vassal (see Fig. 6). In the corner, another attendant brings in tea through the sliding door. In his sleeve is a woodblock print with people of the world-monochrome, but he is hoping to get it coloured at the shop when he has the money. He will then tell his friends about the Barajiru (in seventeenth-century Japanese 


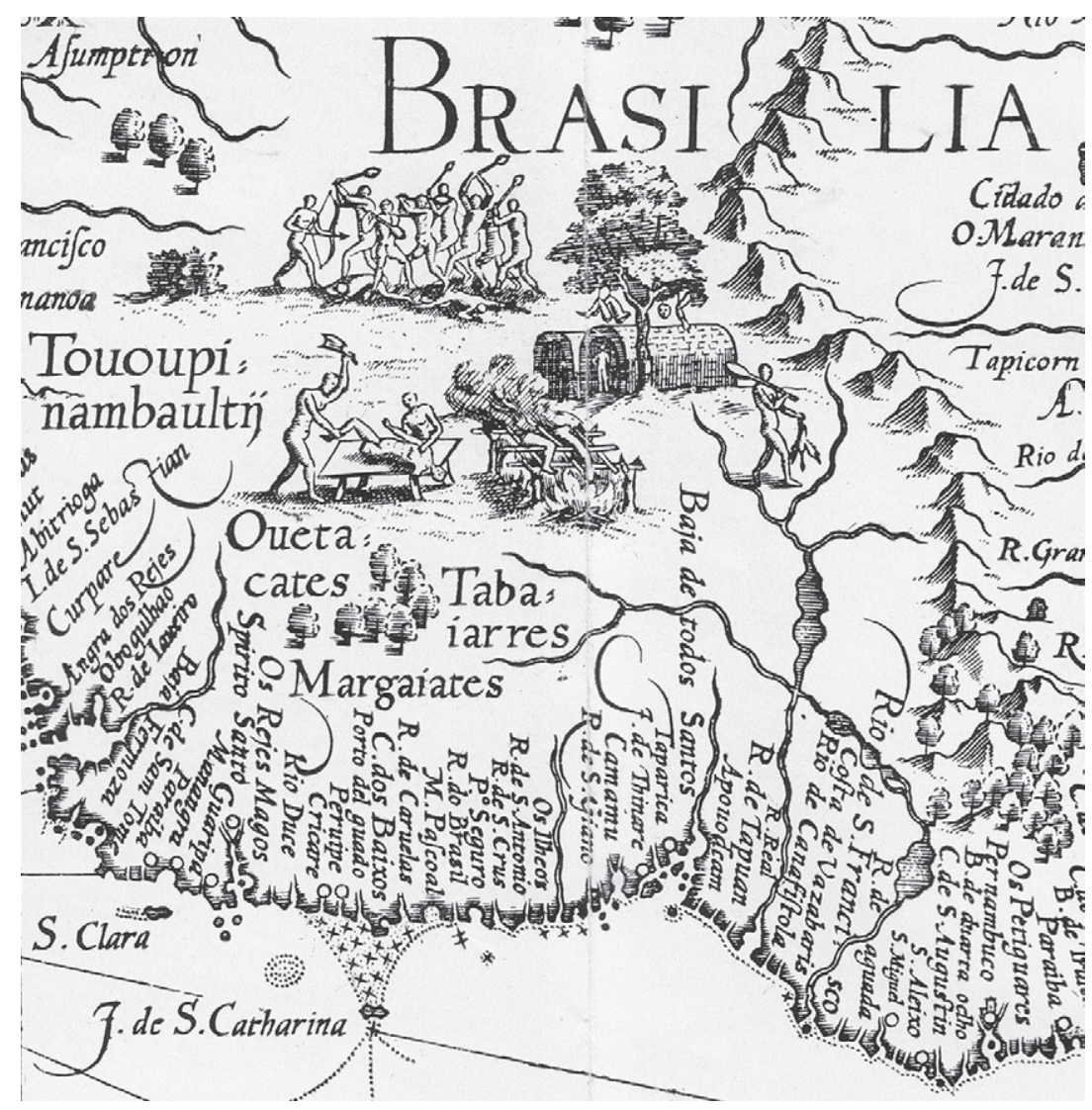

Figure 4. Detail of Afbeeldinghe van alle de zee-custen des gheheelen Zuyderschen deels van America, genaempt Peruviana, enz., attached to Jan Huyghen van Linschoten's Itinerario. Digital image (C) Stichting Digitale Bibliotheek voor de Nederlandse Letteren (dbnl), Leiden.

sources: Brazil) people, who 'live in holes and like to eat human flesh. They eat men but do not eat women. In childbirth, the men have labor pains; the women do not have pain'19 (see Fig. 7).

In the adjacent room, historians of art and cartography discuss the insertion of European scenes of cannibalism into the early seventeenthcentury Japanese context. Art historian Alexandra Curvelo notes that in 1590 , the Jesuits established a mission in Japan, which included a painting workshop. ${ }^{20}$ Cartographic materials were central to Jesuit proselytizing efforts in East Asia, their reproduction and display 


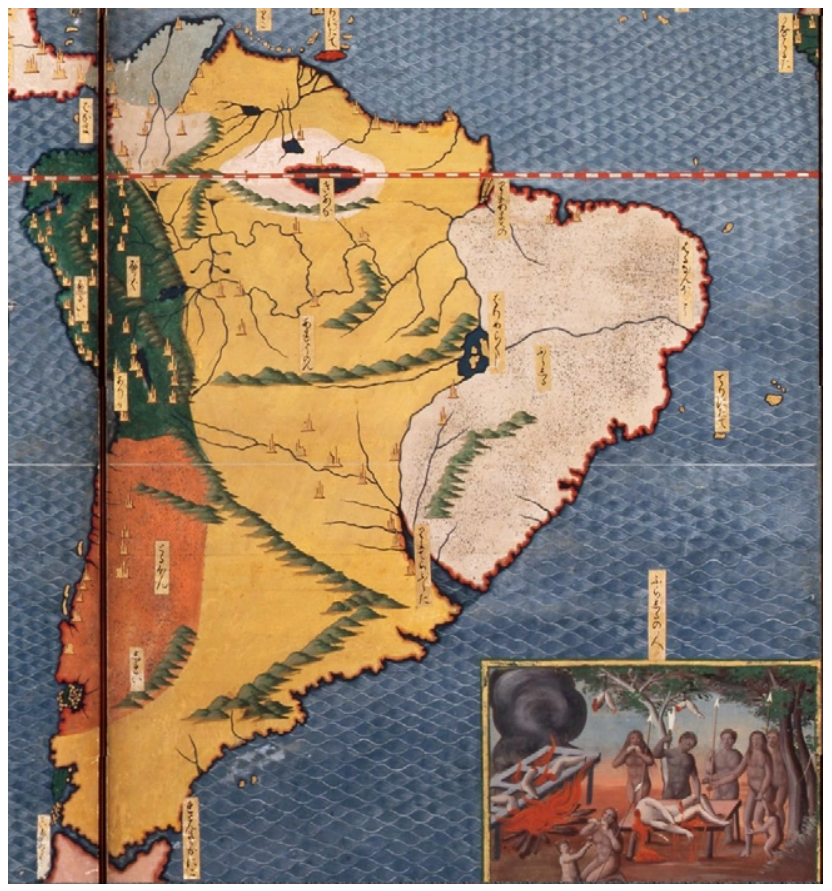

Figure 5. Detail of Folding Screen with Map of the World, i62os, left of a pair of six-fold screens, ink, colour, and gold leaf on paper, ${ }^{5} 53.5$ by $379.0 \mathrm{~cm}$. Digital image (C) Kōsetsu Museum of Art, Kōbe.

promoted as a way for new converts to attain knowledge and power. ${ }^{2 \mathrm{I}}$ Art historian Grace Vlam, the authority on sixteenth- and seventeenthcentury hybrid artworks resulting from interactions between Portuguese and Japanese culture, states: 'It is certain that specifically Dutch geographic material was used by painters of the Jesuit painting school for some important extant folding screens. ${ }^{22}$

Among these folding screens is a lavish pair (see Fig. 5). ${ }^{23}$ The left screen features a cartouche with scenes of anthropophagy to the right of South America. Vlam suggests the maps included in Linschoten's Itinerario as a possible source ${ }^{24}$ and this suggestion is supported by the historian Derek Massarella, who argues for the probability of the Itinerario being on the Dutch ship De Liefde, shipwrecked on the western coast of Japan in I6oo. The ship's contents were confiscated by Jesuits working for the Japanese authorities. ${ }^{25}$ The Itinerario maps might have 

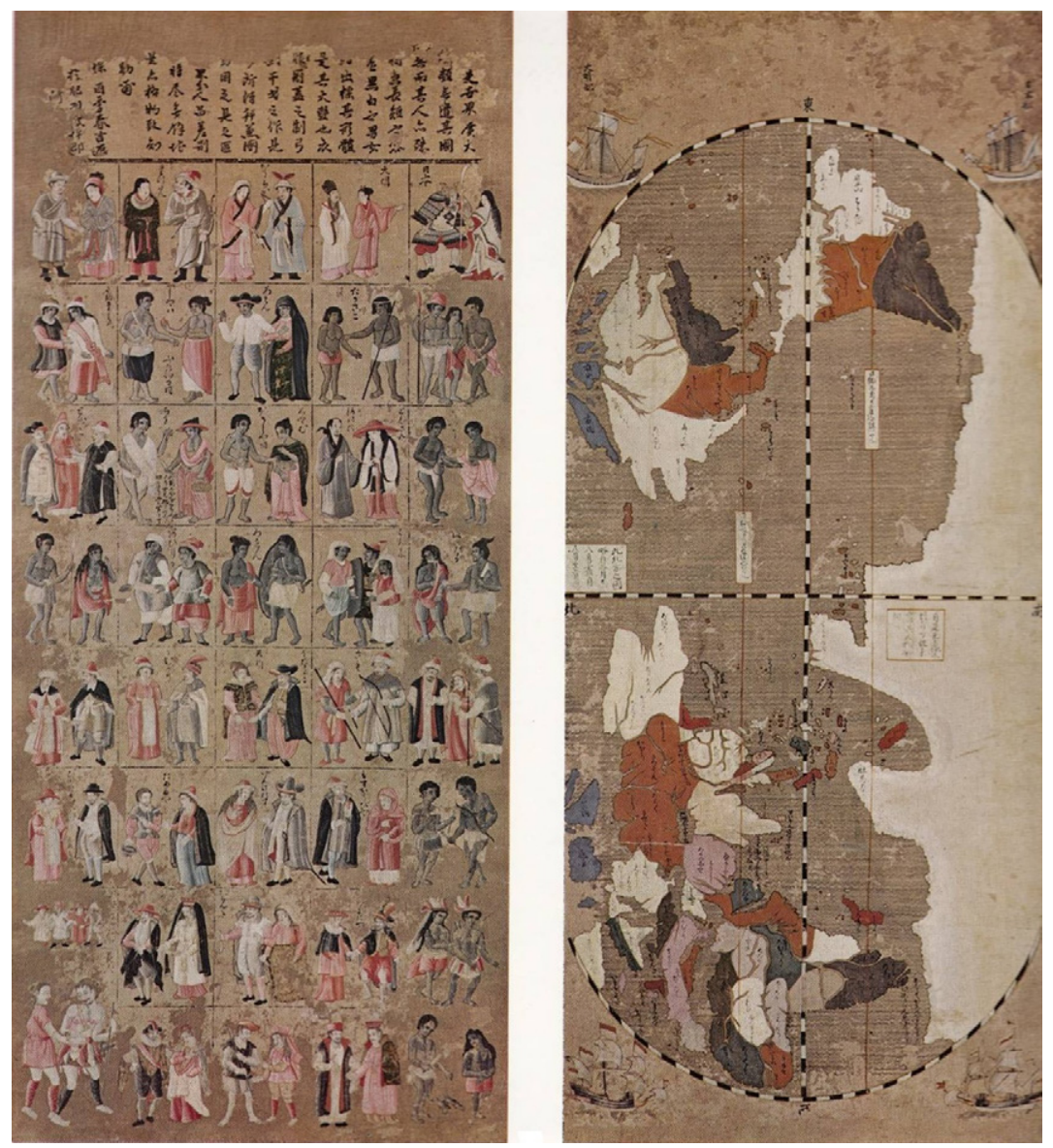

Figure 6. Bankoku sōzu, two-fold screen, wood-cut print with colour brush-worked on paper, I35.8 by $59.2 \mathrm{~cm}$, Digital image (C) Kōbe City Museum of Nanban Art.

thus found their way to the painting school, where they were creatively adapted to the specifically Japanese format of the folding screen.

Art historian Tomoko Gotō interprets the cannibal cartouche above as 'a symbol of "savages" and "heathens" who had to be "civilized" through conversion to Christianity'. ${ }^{26}$ However, the concern with visual impact is at least as evident as the Christianizing mission: no overt Christian iconography is shown, and the bright contrasting colours seem to be indigenous aesthetic choices. 


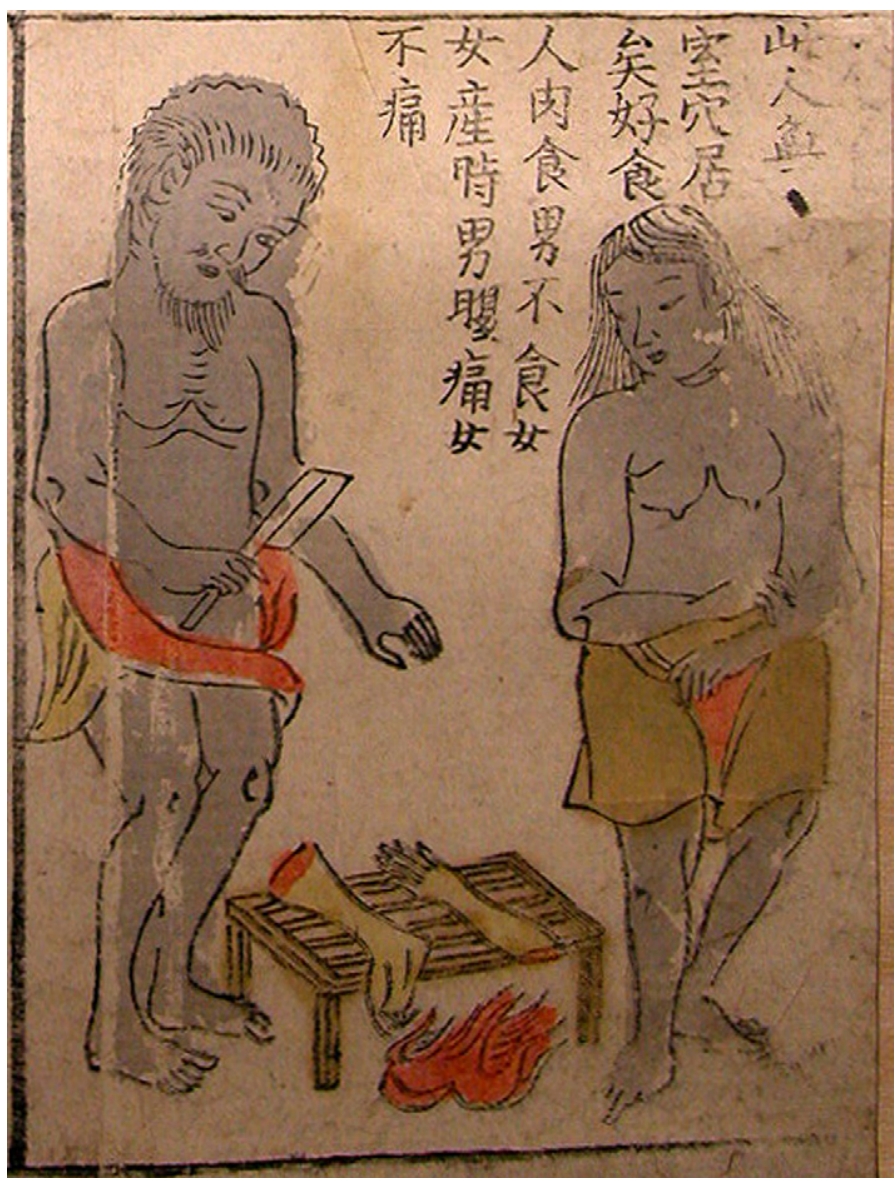

Figure 7. Detail of Bankoku jinbutsu $z u, \mathrm{I} 645$, woodblock print with hand-colouring, Nagasaki. Digital Image (C) The Kyushu University Museum Digital Archive.

Eventually, these visual elements were de-contextualized from the proselytizing context and employed for purposes of entertainment. This happened when the iconography of the screens was adapted by enterprising Japanese publishers to increasingly cheaper woodblockprinted versions. The first was Bankoku sōzu ('Complete Map of the Myriad Countries'), printed in Nagasaki in I645 (see Fig. 6). It is a diptych, with a map of the world on the right, and a set of forty-two cartouches with people of the world on the left. The idea of representing a country by a couple of its inhabitants is taken from European 
cartographic marginalia, but in the Japanese versions they are assembled as a separate group, an anthropological classification avant la lettre. ${ }^{27}$ In Figure 6, on the top right is a Japanese couple, then Chinese and Korean couples, and the list goes on in the order of progressively lower levels of civilization depending on the distance from the cultural centre. 'Brazilians' are at the very edge of this worldview, a peripheral Other within an updated Japanese worldview informed by European culture.

Commercial maps such as Bankoku sōzu were, along with travel narratives, the main agents in a cultural discourse which cultural historian Marcia Yonemoto calls 'the spatial vernacular of the Tokugawa period', consisting of 'a visual/verbal play on meanings familiar to early modern readers' ${ }^{28}$ This semiotic plasticity was applied to the peripheral Others: Toby points out that the tag of the territory previously identified with 'Brazil' changed to 'Cannibal Land' in printed Japanese versions, and the features of its inhabitants were gradually exaggerated. ${ }^{29}$

In some versions, this vernacularization was taken one step further: the label was changed from Barajiru ('Brazil') to yamabito (山人 'mountain people'), an indigenous model of peripheral Others (see Fig. 7). ${ }^{30}$ The peripheral location of the cannibals facilitated their appropriation: in the next section we will see how concepts of anthropophagy already present in Japanese culture played a major role in the transformation of 'Brazilians' into 'mountain people'.

III

I switch off the second TV screen, and switch on the third. A rustling wedding banquet in a mid-seventeenth-century town house in the new capital Edo. A print showing people of the world is displayed in the tokonoma ('alcove'). ${ }^{3}$ ${ }^{\text {I }}$ Heirloom items scattered throughout the room include scrolls rolled open. The first is a copy of a sixteenth-century depiction of an otogi zōshi ('companion tale'). The father of the bride, a wealthy merchant, relishes in showing it to his inebriated guests. The story tells of the ogre Shuten Dōji, who has been abducting imperial princesses with the help of his demon acolytes and taking them to his lair in Mount Ōe near the old capital Kyōto:

With horrifying regularity, the demons would seize one of the captive ladies and take her to a place called the 'jail', where they pressed her body for blood. This they then served, calling it 'sake'. A magic potion kept the woman from dying, so that they could press her several times, but eventually they butchered her and served her flesh, calling it 'fish'. ${ }^{2}$ 


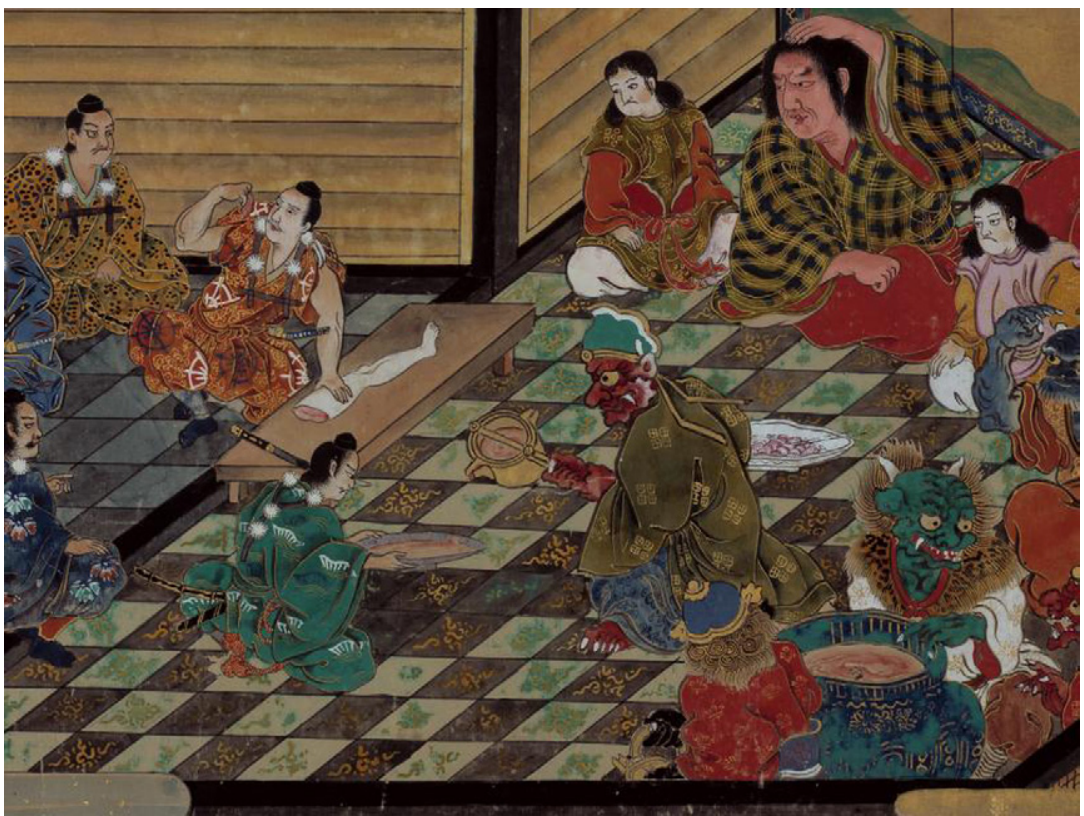

Figure 8. Illustration to the The Tale of the Demon Shuten-Dōji, second of three illustrated scrolls, ink, color, and gold on paper, $26.2 \mathrm{~cm}$ high. Digital image (C) Keiō University Library, Tōkyō.

A band of warriors is sent by the emperor to rescue the princesses. Disguised as mountain priests, the warriors wade through the mountains and are welcomed by the child-shaped ogre in his palace. Here they have to drink human blood and eat princess thigh sushi to uphold their disguise (see Fig. 8). They then get the demons drunk and slay the ogre in his bedchamber, destroying his lair and returning the princesses to the capital.

Next to this scroll, another is slowly being unrolled (the camera zooms in). It illustrates a prequel to the first story, following the birth and adventures of the young ogre on another mountain, Ibuki. It also depicts a cannibalistic banquet. However, here only demons eat princess flesh (see Fig. 9). And in a corner, the tipsy groom is listening to his friend explain the plot of the latest puppet theatre play based on the Ibuki story. The tale of Shuten Dōji originated in the fourteenth century and enjoyed numerous reiterations. ${ }^{33}$ It provides a cultural precedent for scenes of anthropophagy within Japanese culture, prior to the insertion 


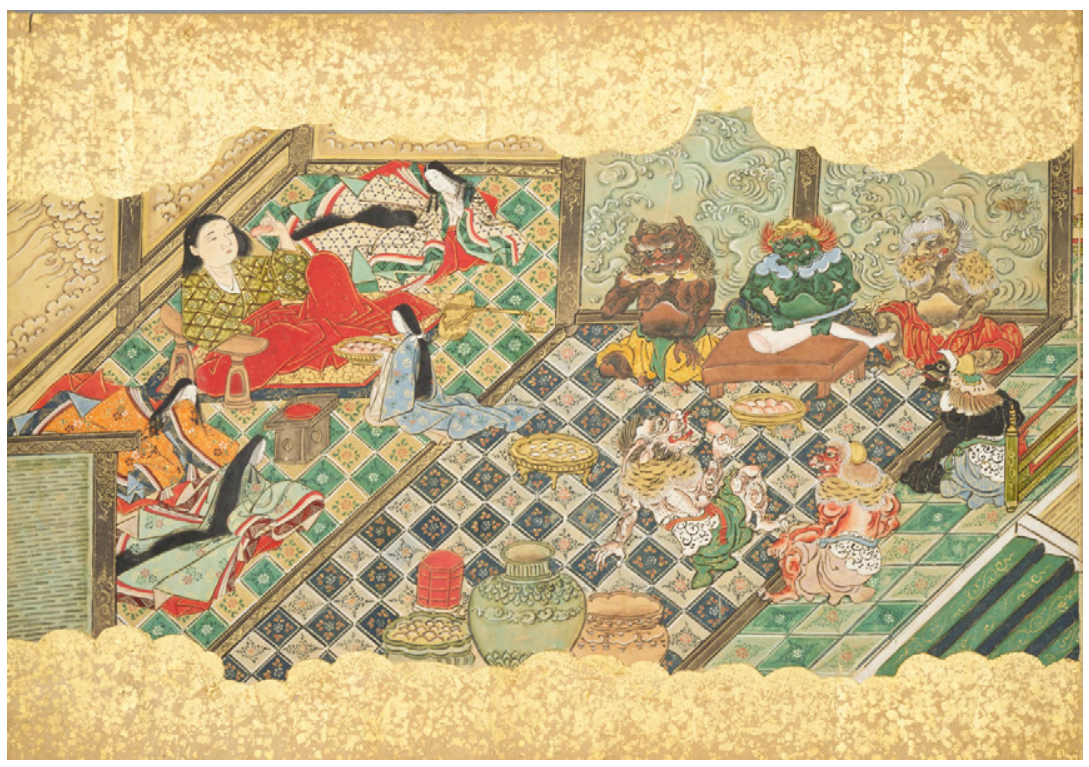

Figure 9. Detail of illustration to The Tale of the Demon Shuten-Dōji, illustrated scroll, ink, color, and gold on paper, 34.I cm high, Digital image (C) National Diet Library, Tōkyō.

of European images of Brazilian cannibalism. In the researchers' room, anthropologists and art historians discuss three issues: the gender coding of the tale, its topology, and the contexts in which the tale was used. The first issue of gender coding is broached by art historian Kamei Wakana, who argues for an alternative reading of the influential illustration of the tale by the painter Kanō Motonobu in I 522. Kamei notices the absence of depictions of women from the first scroll, while the second scroll features the sexually charged depiction of the princess's leg and its consumption by the warrior in disguise. These features may be a reflection of malecentred social relations which informed the production of this scroll. ${ }^{34}$

The spatial characteristics of the periphery represented by the ogre's lair are crucial to Kamei's argument. Most depictions of the ogre's lair use iconographic markers indicating a quasi-Chinese architectural setting: tiled roofs, curtains and stone floors (see Fig. 9). However, Kanō Motonobu's scroll inverts this convention by depicting the ogre's lair as an architecturally Japanese space: thatched roofs, wooden structure and tatami mats. ${ }^{35}$ Moreover, Motonobu's depiction of the banquet in the ogre's lair is reminiscent of an elegant renga ('linked-verse') poetry 
gathering, which connoted the cultural centre embodied by the imperial court. In other words, Motonobu refashioned the ogre as a representative of the imperial Kyoto culture, and the warriors as uncouth provincial warlords.

The iconography of Motonobu's scroll version is nevertheless an exception. Most later seventeenth-century depictions of the tale depict the ogre's lair as quasi-Chinese, with tiles and a motley crew of demons (see Fig. 8). Ethnographer Komatsu Kazuhiko confirms that these features correspond to the general characteristics of the otherworld (jp. ikai) in the worldview of Japanese culture. ${ }^{36}$ Its features are constant regardless of location: all types of $i k a i$, whether placed in India, China, a Buddhist paradise, deep mountains or under the sea, have the same look and structure, with a central figure guarding a coveted object or 'treasure'.

For example, medieval historian Takahashi Masaaki points out continuities between the ogre Shuten Dōji and the water deity, usually appearing in the form of the Dragon King in a palace under the sea. Takahashi gives examples of stories placing the Dragon Palace in deep mountains, just like Shuten Dōji's lair. Mountains were thus sites of sacredness and transformation. This is the cultural context for the transformation of 'Brazilians' into 'mountain people'. Within this context, the tale of Shuten Döji provided a specific cultural precedent for scenes of anthropophagy. For the Japanese audience, stories about Brazilian cannibals might have thus brought to mind the princess-eating ogre in the mountains.

Takahashi describes the ambivalent nature of the water deity: both benevolent-bringer of life and prosperity-and malevolent, spreading death and disease through droughts and floods. ${ }^{37}$ This corresponds to the ambivalence of the ogre Shuten Dōji, whom historian of religions Irene Lin describes as a "double signifier" [...] composed of the "demon" and the "child". ${ }^{3}$ Notice the parallel with the ambivalence of the Brazilian cannibal within sixteenth-century European culture: a similar mix of innocence and repulsion, purity and defilement. But unlike the European case, where it was seen as a regressive state, cannibalism within the Shuten Dōji story represented the customary practice of an alternative cultural centre of authority. ${ }^{39}$ According to Komatsu, the human protagonist who enters an otherworld assumes its characteristics. The abnormal behaviour of the warriors is thus perfectly appropriate within the ogre's lair. In the end, however, the warriors' transformation is only a stratagem for annihilating the centre of authority represented by Shuten Dōji's lair. ${ }^{+0}$ The periphery, and its associated Others, thus 
become indispensable for the articulation of the identity of the centre. From the point of view of identity, there emerges a dialectic between categories of centre and periphery. The subversion of the iconography of centre and periphery in Motonobu's scroll version shows how the visual field allowed for a slippage of meaning. This, in turn, enabled the renegotiation of both the identity of the depicted Other and that of the viewer.

This leads into the third issue in the discussion: the context in which illustrated versions of the story were used. Art historian Muraki Keiko mentions the use of the above scroll by Kano Motonobu as a heirloom item for the 5594 marriage between Lady Toku, the second daughter of the general Tokugawa Ieyasu, and the daimy' ('feudal lord') Ikeda Terumasa. From mid-seventeenth-century onward, this practice became widespread among the burgeoning urban middle-class population. ${ }^{4 \mathrm{I}}$ But how could this gruesome story have been used on such an auspicious occasion? None of the researchers in the room address this question, so I feel compelled to intervene. I believe Shuten Dōji's story was interpreted as a straightforward tale of saving princesses in distress. Its plot is structured as a rite of passage, with its three phases identified by van Gennep: separation (the abduction of the princesses and the warriors' approach through the mountains), transition, or the liminal stage (the consumption of the princesses and the warriors' transformation) and reincorporation (the return of the saved princesses to the capital)..$^{42}$ The peripheral setting of the ogre's lair, and the scene of anthropophagy occurring within, correspond to the liminal stage of a rite of passage. Visiting the periphery and engaging in anthropophagic practices constitutes the prelude to a change in identity. The story thus provides a fitting parallel to marriage, a rite of passage that places the bride (as princess) in a liminal state. The consumption of the princesses by the warriors may thus have functioned as a fictional counterpart to the consumption of the marriage by the bride and groom.

Nonetheless, the anthropophagic scene sits uncomfortably in this new context. Conversely, there are illustrated versions of the story in which the scene is omitted, or depicted as being performed by demons, in standard otherworld fashion (see Fig. 9) ${ }^{43}$ Gender politics is again manifest, but this time with the opposite effect: it contributes to the taming of the tale, making it more palatable to the auspicious occasions of middle-class audiences. This iconographical change parallels that between Hans Staden's and Theodore de Bry's visualizations of Brazilian cannibals, discussed in the first section. 
I switch on all three TV sets, displaying slideshows with the images discussed, zooming in and out. The first case study showed a transformation of testimonies of encounter with the Other into a spectacular display of deviation accommodated to pre-existing visual conventions. The second case showed the vernacularization of cartographic marginalia into indigenous models of peripheral alterity. And the third case showed how the dynamics of pre-existing images of anthropophagy formed a context for the reception of European scenes of cannibalism. Can these three case studies help us define a model of the construction of the Other?

I propose to describe the relationship between centre and periphery during the process of construction of the Other with the figure of speech of metonymy. ${ }^{44}$ In my understanding, the centre constructs the periphery and its inhabitants through metonymy, both intraculturally and interculturally. Cannibals are a metonymy of all Others, their behaviour stands for all abnormal behaviours. Gnawed limbs are a metonymy for the dissolution of the body, and by extension the dissolution of the self. Cannibals are thus a model of 'radical alterity' which was shared by both European and Japanese cultures. ${ }^{45}$

Intraculturally, telling stories with unusual characters and settings is the basic way in which we understand the world and concomitantly define ourselves..$^{4}$ Narratives of anthropophagy thus coagulated identities at the margins of both European and Japanese cultures.

Interculturally, interaction occurs when cultures slide across the margins, lubricated by reciprocal metonymic images of the Other. Thus, for European culture, Japan was (and still is) a peripheral Other constructed metonymically. Likewise, within Japanese culture, the idea of Europe has been associated with peripheral Others. Intercultural communication is thus normally established through peripheries where metonymies of the Other are pitched. The peripheral interfaces are double layered. The interior layers correspond to narrative tropes shared intraculturally: the noble/sinful savage, the splendid demon, respectively. The exterior layer is the narrative self-representation of a culture towards another, which includes the peripheral model of the Other, configured as the inversion of the normative centre. The initial use of images of Brazilian cannibals in Japan, for example, was an attempt at introducing such a peripheral model of the Other to the Japanese audience (see Fig. 5). The acceptance of this peripheral image of 
cannibals would have entailed the acceptance of its central counterpart, the Christian doctrine.

However, the model outlined above does not allow direct intercultural contact between centres. It describes interacting interfaces wrapped around a postmodern 'empty signifier'. A solution is given by the philosopher Gilles Deleuze, who reverses the traditional philosophical primacy of identity over difference by proposing a concept of identity that 'revolves around the Different' ${ }^{47}$ Instead of a model of interaction between self-sufficient identities which project ontologically simplified metonymic inversions of themselves at the points of peripheral contact, Deleuze proposes that identity is defined at these very points. This enables the metonymical construct of the Other to gain a full ontological status - not as a simplified inversion of a normative central identity (such as white European man), but as the playing out of a temporary, relational identity which does not exist outside interactions with other entities. ${ }^{8}$

The insertion of a third element-images of cannibals - in a dyadic intercultural relationship facilitates the sharing of a relational identity between two central identities sharing an image of the peripheral Other. The confluence of metonymies allowed a connection through the seams between the exterior and interior layer; the possibility of intercultural communication between ontological centres was thus briefly realized. The exterior layer-an image of 'spectacular anthropophagy'-was shared by Europe and Japan. ${ }^{49}$ Both in Europe and Japan, the initial irruption of an unprecedented Other enabled the reconfiguration of the narrative of identity by reengaging with the periphery where these unprecedented Others appeared-as though the two cultures came together and said: 'We've got the same Others, we could be the same!'

However, this possibility for a paradigm change could only have been maintained by direct, personal interaction, such as Hans Staden's odyssey, or Jesuit proselytism. As soon as it was reproduced intraculturally, this interaction was engulfed by the cultural inertia made up of precedents and tradition - the interior layer of the metonymic Other. The disruptive potential of the Other was thus tamed and objectified as figures of display and entertainment.

Visual elements are especially suited for this metonymical model of intercultural interaction. Unlike narrative elements, which aim for closure and semiotic fixity, visual elements are slippery both in their meaning and their transmission. Their dynamics disclose the improvisational nature of identity construction. Images of Brazilian 
cannibals are an example of the overflow of the visual elements of identities constructed at the margins..$^{50}$ The anecdotal and visual elements of the illustrations wander out into other media, unbounded by emplotment, sequentiality, temporality and other features of narrative. This visual excess is what we researchers now feed on, just like old Tupi women, licking the blood oozing out of the body of discourse.

Thank you for watching.

See you next time on CCS channel!

\section{NOTES}

I I thank Professor Morihiro Satow from Kyōto Seika University for the opportunity to present a draft of this article at his graduate seminar. The Library of The Institute for Research in Humanities, Kyōto University facilitated research for this article.

2 I am adapting the methodology defined by psychotherapist Donald Polkinghorne as 'narrative-type narrative inquiry' in 'Narrative Configuration in Qualitative Analysis', International Fournal of Qualitative Studies in Education, 8. I (I995), 5-23 (p. 5).

3 For a detailed account of Linschoten's role in the first Dutch expeditions to Asia, see Arun Saldanha, 'The Itineraries of Geography: Jan Huygen van Linschoten's Itinerario and Dutch Expeditions to the Indian Ocean, I594-I602', Annals of the Association of American Geographers, Iог. I (200I), I49-177 (р. г6г).

4 Jan Huygen van Linschoten, Itinerario, voyage ofte schipvaert van Fan Huygen van Linschoten naer Oost ofte Portugaels Indien (Amsterdam, I596), p. I5: $<$ http://www.dbnl.org/tekst/saveas.php?filename=linsooritino4_or .pdf\&dir=/ arch/linsoo Iitino4_oI $/$ pag\&type $=$ pdf\&common $=_{\mathrm{I}}>$ [accessed I5 September 20I3]; translated by William Phillip as Iohn Huighen van Linschoten His Discours of Voyages into ye Easte $\mathcal{E}$ West Indies: Devided into Foure Bookes (London, I 598), p. 255 : < http://books.google.at/books/ucm? vid=UCM $5324330456>$ [accessed I5 September 2013]. I have retained the spelling and punctuation of the English translation.

5 Joan-Pau Rubiés, 'Text, Image and the Perception of Savages in Early Modern Europe: What We Can Learn from White and Harriot', in European Visions: American Voices, edited by Kim Sloan, British Museum Research Publication, I72 (2009), pp. I20-I30 (p. I2 I).

6 Ibid., p. I22.

7 William Arens, The Man-Eating Myth: Anthropology and Anthropophagy (Oxford and New York: Oxford University Press, I980).

8 Rubiés, p. I23.

9 Ibid., p. I24.

Io Neil Whitehead, 'The Ethnographic Lens in the New World: Staden, de Bry, and the Representation of the Tupi in Brazil', in Early Modern Eyes, edited by Walter S. Melion and Lee Palmer Wandel (Leiden: Brill, 20 Io), pp. 8I-IO4 (p. 82).

I I Whitehead, pp. 87, 97-98. 
I2 I am referring to visual tropes of nudity in engravings originating with the ${ }_{527} I$ Modi, based on designs by Raphael's disciple Giulio Romano. See Bette Talvacchia, Taking Positions: On the Erotic in Renaissance Culture (Princeton, NJ: Princeton University Press, I998). The classical poses are discussed in Merrall Price, Consuming Passions: The Uses of Cannibalism in Late Medieval and Early Modern Europe (New York: Routledge, 2003), p. I02.

I3 Bernadette Bucher, La sauvage aux seins pendants (Paris: Hermann, I977), pp. 55-77.

I4 Rubiés, p. I20.

I 5 An idea explored by Michel de Montaigne in his essay 'Des Cannibales' from his I 580 Essais. See Caroline Locher, 'Primary and Secondary Themes in Montaigne's “Des Cannibales" (I, 3I)', French Forum, I.2 (I976), I I9-I26.

I6 Whitehead, p. 94.

I 7 They were inspired not by de Bry's illustrations, but by similar ones by André Thevet from his ${ }_{55} 8$ Les singularitez de la France antarctique autrement nommée Amérique. For a detailed discussion see Saldanha, p. I 55 and Cornelis Koeman, Jan Huygen van Linschoten (Lisbon: Instituto de Investigação Científica Tropical, I984), pp. 38-40.

I8 Koeman, p. 4I.

I9 Text accompanying the illustration of 'mountain people' in Bankoku jinbutsu zu, translated in Ronald Toby, "Three Realms/Myriad Countries: An "Ethnography" of Other and the Re-bounding of Japan, I550-I750', in Constructing Nationhood in Modern East Asia, edited by Kai-wing Chow and others (Ann Arbor: University of Michigan Press, 200I), pp. I 5-47 (p. 27).

20 Alexandra Curvelo, 'Nagasaki: An European Artistic City in Early Modern Japan', Bulletin of Portuguese/Fapanese Studies, II (200I), 23-35, and Angelo Cattaneo, 'The Mutual Emplacement of Japan and Europe during the Nanban Century', in Portugal, Jesuits, and Japan. Spiritual Beliefs and Earthly Goods, edited by Victoria Weston (Boston: McMullen Museum of Art, Boston College, 20I3), pp. 25-33 (p. 29).

2I Alexandra Curvelo, 'Copy to Convert: Jesuits' Missionary Artistic Practice in Japan', in The Culture of Copying in Japan: Critical and Historical Perspectives, edited by Rupert Cox (London: Routledge, 2008), pp. I I I-I 27 (p. I I 7).

22 Grace Vlam, 'Western-Style Secular Painting in Momoyama Japan' (unpublished doctoral thesis, University of Michigan, I976), p. I7. Also Curvelo, 'Copy', p. i I 8.

23 Now in the Kōsetsu Museum in Kōbe; classified in the 'Kaerius group' of five folding screens with maps probably inspired by the I6o9 world map of Pieter van den Keere. See Miyoshi Tadayoshi, 'P. Kaeriusu I6o9 nenban sekai chizu wo megutte', Kōbe shiritsuhakubutsukan kenkyūkiyō, I3 (I997), I5-43, and “'Bankoku ezu byōbu" no genzu ni tsuite - I6o9 nenban P. Kaeriusu sekai chizu no fukugen', Kōbe shiritsuhakubutsukan kenkyūkiyō, I9 (2003). Also Odaira Shūichi, 'Nihon ni okeru Minami Amerika ninshiki no gensho keitai - nanbankei sekaichizubyōbu ni mirareru morojōhō wo megutte', Idemitsu bijutsukan kenkyūkiyō, 2 (I996), I3-48.

24 Vlam, p. I33.

25 Derek Massarella, A World Elsewhere: Europe's Encounter with fapan in the Sixteenth and Seventeenth Centuries (New Haven, CT: Yale University Press), p. 78. The pilot of De Liefde was the Englishman William Adams, who famously became a nautical advisor to the shoggun Tokugawa Ieyasu.

26 Tomoko Gotō, 'Emergent Consciousness About the Self Depicted in the World Map Screens', (unpublished MA dissertation, University of British Columbia, 200o), p. 56. 
27 Mia Mochizuki, 'The Movable Center: The Netherlandish Map in Japan', in The Market for Exposure. Reimagining Cultural Exchange between Europe and Asia, I400-I900, edited by Michael North (Aldershot: Ashgate, 2009), pp. 77-89. See also Ronald Toby, 'Imagining and Imaging “Anthropos” in Premodern Japan', Visual Anthropology Reviem, I4.I (I999), I9-44 (pp. 23, 29).

28 Marcia Yonemoto, 'The "Spatial Vernacular" in Tokugawa Maps', The Journal of Asian Studies, 59.3 (2000), 647-666 (pp. 648, 66o). See also Marcia Yonemoto, Mapping Early Modern Japan: Space, Place, and Culture in the Tokugawa Period (I603-I868) (Berkeley: University of California Press, 2003), pp. I-5.

29 Toby, 'Imagining', p. 31. Concomitantly, versions of Matteo Ricci's Sinicized map of the world circulating in Japan featured the label 'Cannibal Land' 食人国 near Salvador de Bahia, perhaps adapting Linschoten's map of South America. See Curvelo, 'Copy', pp. г I6-i I7; Kazutaka Unno, 'Cartography in Japan', in History of Cartography, edited by John Brian Harley and David Woodward (Chicago: University of Chicago Press, I994), pp. 346-477 (pp. 404-405, 407-410).

30 The concept of yamabito was central to the work of Japanese ethnographer Yanagita Kunio as a marginal social category preserving the original folk beliefs of Japan. However, the exact meaning of yamabito before its nineteenth-century advocacy by Yanagita is unclear. See Hideyo Konagaya, 'Yamabito: From Ethnology to Japanese Folklore Studies', The Folklore Historian, 20 (2003), 47-59. For the concept of the Other within Japanese culture, see Akasaka Norio, Ijinron josetsu (Tōkyō: Sunagoya Shobō, I985); Komatsu Kazuhiko, Ijinron (Tōkyō: Seidosha, I985); Carmen Blacker, 'The Folklore of the Stranger: A Consideration of a Disguised Wandering Saint', Folklore, гог.2 (1990), г62-г68.

3 I Unno, p. 405 .

32 Eugene Quitman, 'The Price Shuten Dōji Screens: A Study of Visual Narrative', Ars Orientalis, 26 ( I996), I-2 I (p. I I).

33 See Noriko Reider, 'Shuten Dōji: "Drunken Demon”, Asian Folklore Studies, 64.2 (2005), 207-23I.

34 The social gap between the commissioner, provincial warlord Hōjō Ujitsuna, and the painter Kanō Motonobu and the calligraphers, who were members of Kyōto aristocracy, might have led to strained relations reflected in depictions of women as objects of sexual desire. The provincial warlords' dabbling into Kyōto culture would have been considered by its aristocracy as uncouth as eating the foot of a Kyōto lady. See Wakana Wakana, 'Josei hyōshō kara miete kuru otokotachi no kankei: Kanō Motonobu hitsu "Shuten dōji emaki" kaishaku no arata na takumi', in Bijutsu to jendā 2: kōsa suru shiten, edited by Suzuki Tokiko and others (Tokyo: Bruecke, 2005), pp. 47-8o (pp. 55, 49, 57, 69).

35 These conventions were adapted from the visual idiom of medieval Japanese scrolls. See Kuroda Hideo, 'Otogi zōshi no ega kōdoron nyūmon', in Rekishi to shite no otogi zōshi (Tokyo: Perikansha, I996), pp. 27 I-298 (pp. 279-288).

36 See Komatsu Kazuhiko, Ikai to Nihonjin: emonogatari no sōzōryoku (Tokyo: Kadokawa Shoten, 2003).

37 Takahashi Masaaki, Shuten Dōji no tanjō: mō hitotsu no Nihon bunka (Tokyo: Chūō Kōronsha, I992), p. I36.

38 Irene H. Lin, 'The Ideology of Imagination: The Tale of Shuten Dōji as a Kenmon Discourse', Cahiers d'Extrême-Asie, I3 (2002), 379-4Iо (p. 380). 
39 The concept of oni (demons), of which the ogre Shuten Dōji is a representative example, might have originated in stories about banished political rivals. See Baba Akiko, Oni no kenkyu (Tokyo: San'ichi Shobo, I97I), pp. I4I, I50. Also Noriko Reider, Fapanese Demon Lore: Oni, from Ancient Times to the Present (Logan: Utah State University Press, 2010), pp. 42-48.

40 See Lin, p. 39r.

4I Muraki Keiko, 'Chōgonka no henyō-naraekei "Chōgonka emaki” wo tegakari ni', Bijutsugeijutsugaku (Dōshisha daigaku bijutsugeijutsugakka), 25 (2009), 50-69 (p. 66).

42 Arnold van Gennep, Les rites de passage (Paris: Emile Nourry, I909), translated by Monika Vizedom and Gabrielle Caffee as The Rites of Passage (London: Routledge, 2004).

43 I am referring to less numerous examples of an alternative textual genealogy focusing on the biography of the ogre Shuten Dōji in Mount Ibuki. In the late seventeenth-century version in the British Museum, the demons are slaying a deer instead of a princess. A reproduction is available at $<$ http://www.britishmuseum. org/research/collection_online/collection_object_details/collection_image_gallery. aspx? partid $=\mathrm{I} \&$ assetid $=$ I2686 $\mathrm{I} 9$ \&objectid $=790280>$ [accessed I 5 May 20 I 4 ].

44 I am inspired by Maria Tymoczko's use of metonymy in the context of translation studies, especially in Translation in a Postcolonial Context: Early Irish Literature in English Translation (Manchester: St Jerome, I999). I am grateful to Dorota Gołuch for drawing my attention to Tymoczko's work. Metonymy also informs the topological model of the Other theorized by the historian of religions Lawrence Z. Smith in 'Differential Equations: On Constructing the Other', in Relating Religion (Chicago: University of Chicago Press, 2004), p. 23I, discussed in Carole A. Myscofski, 'Imagining Cannibals: European Encounters with Native Brazilian Women', History of Religions, 47.2/3 (2007-2008), I42-I 55. Tobias Wendl uses a similar figure of speech for a host culture constructing a 'synecdochical representation' of a foreign culture, in 'Spirit Possession, Slavery and Ritual Consciousness: A Case Study of the Tchamba Cult among the Mina in Togo', in Spirit Possession, Power and Modernity in Africa, edited by Heike Behrend and Ute Luig (London: James Currey, I999), pp. I II-I23 (p. I I6). Alternatively, in Alexandra Curvelo, 'The Disruptive Presence of the Namban-jin in Early Modern Japan', Fournal of the Economic and Social History of the Orient, 55 (2012), 58I-602 (p. 59I), parataxis is proposed as a model for intercultural interaction. However, this implies an intercultural communication on equal terms, which, as this programme shows, is never possible because communication occurs through metonymical constructs.

45 I borrow the term 'radical alterity' from Tzvetan Todorov, La conquête de l'Amérique: La question de l'autre (Paris: Seuil, I982), translated by Richard Howard as The Conquest of America: Perceiving the Other (New York: Harper \& Row, 1984).

46 See the 'narrative concept of identity' in Margaret Somers, 'The Narrative Constitution of Identity: A Relational and Network Approach', Theory and Society, 23 (1994), 605-649 (pp. 6r3-6r4).

47 Gilles Deleuze, Différence et Répétition (Paris: Presses Universitaires de France, I968), translated by Paul R. Patton as Difference and Repetition (New York: Columbia University Press, I994), p. 50. 
48 My thoughts are inspired by the cultural geographer Mike Crang's relational concept of identity in Cultural Geography (London; New York: Routledge, I998), p. 6I, and political geographer Noel Parker's concept of 'the margin' in 'From Borders to Margins: A Deleuzian Ontology for Identities in the Postinternational Environment', Alternatives: Global, Local, Political, 34. I (2009), I7-39 (pp. 29-30). Although my argument refers here to intercultural interaction, it applies to intracultural interaction as well-see Lin, p. 39I.

49 Whitehead, p. 9I.

50 See Michel de Certeau, 'Ethno-graphie: L'oralité, ou l'espace de l'autre: Léry', in L'écriture de l'histoire (Paris: Gallimard, I975), pp. 2I 5-248, translated by Tom Conley as 'Speech, or the Space of the Other: Jean de Léry', in The Certeau Reader, edited by Graham Ward (Oxford: Blackwell Publishing, 2000), pp. I29-I49 (p. I40). Also Ben Highmore, Michel de Certeau: Analysing Culture (London: Continuum, 2006), p. 72. 